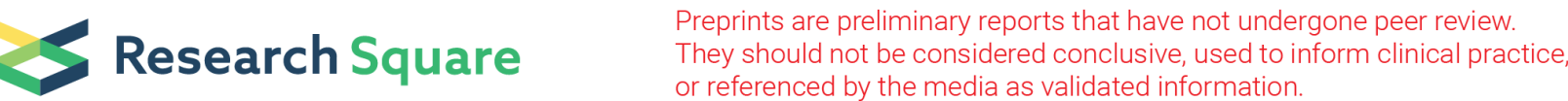

\section{Increasing The Grain Yield And Grain Protein Content of Common Wheat (Triticum Aestivum) By Introducing Missense Mutations In The $Q$ Gene}

\section{Qing Chen}

Sichuan Agricultural University

\section{Zhenru Guo}

Sichuan Agricultural University

\section{Xiaoli Shi}

Sichuan Agricultural University

Meiqiao Wei

Sichuan Agricultural University

Yazhen Fan

Sichuan Agricultural University

Jing Zhu

Sichuan Agricultural University

Ting Zheng

Sichuan Agricultural University

Yan Wang

Sichuan Agricultural University

Li Kong

Sichuan Agricultural University

Mei Deng

Sichuan Agricultural University

\section{Xinyou Cao}

Shandong Academy of Agricultural Sciences

Jirui Wang

Sichuan Agricultural University

Yuming Wei

Sichuan Agricultural University

Qiantao Jiang

Sichuan Agricultural University

\section{Yunfeng Jiang}

Sichuan Agricultural University

\section{Guoyue Chen}


Sichuan Agricultural University

\section{Youliang Zheng}

Sichuan Agricultural University

Pengfei Qi ( $\sim$ Pengfeiqi@hotmail.com )

Sichuan Agricultural University https://orcid.org/0000-0002-7772-9591

\section{Research Article}

Keywords: wheat quality, agronomic trait, mutation, breeding

Posted Date: September 23rd, 2021

DOI: https://doi.org/10.21203/rs.3.rs-899571/v1

License: (9) This work is licensed under a Creative Commons Attribution 4.0 International License. Read Full License 


\section{Abstract}

Grain yield (GY) and grain protein content (GPC) are important traits for wheat breeding and production; however, they are usually negatively correlated. The $Q$ gene is the most important domestication gene in cultivated wheat because it influences many traits, including GY and GPC. Additionally, $Q^{c 1}$ is an overexpressed $Q$ allele containing a missense mutation in the microRNA172-binding site. The common wheat (Triticum aestivum) mutant $S-C p 1-1$, which carries $Q^{c 1}$, has a very high GPC and some unfavorable characteristics, including dwarfism and compact spikes, which decrease the GY. We previously suggested that missense mutations in the sequences encoding the $\mathrm{AP}_{2}$ domains of $Q^{c 1}$ can be exploited to enhance the agronomic performance of wheat. In this study, we characterized two new $Q$ alleles $\left(Q^{s 1}\right.$ and $\left.Q^{c 1}-N 8\right)$. Compared with the wild-type $Q$ allele, $Q^{s 1}$ contains a missense mutation in the sequence encoding the first $\mathrm{AP}_{2}$ domain, whereas $Q^{c 1}-N 8$ has two missense mutations, one in the sequence encoding the second $\mathrm{AP}_{2}$ domain and the other in the microRNA172-binding site. The $Q^{s 1}$ allele did not significantly affect the GPC or other processing quality parameters, but it adversely affected the GY by decreasing the thousand kernel weight and grain number per spike. In contrast, $Q^{c 1}-N 8$ positively affected the GPC and GY by increasing the thousand kernel weight and grain number per spike, thereby reversing the unfavorable agronomic characteristics resulting from $Q^{c 1}$. Thus, we generated a novel germplasm relevant for wheat breeding. Furthermore, our findings provide new information useful for enhancing cereal crops via nontransgenic approaches.

\section{Key Message}

A new $Q$ allele, $Q^{c 1}-N 8$, was generated by optimizing the expression and the $\mathrm{AP}_{2}$ domain-encoding sequence of the $Q$ gene. The $Q^{c 1}-N 8$ allele significantly increased the common wheat grain yield and quality, implying it is useful for enhancing wheat production.

\section{Introduction}

Common wheat (Triticum aestivum) is a major food crop that serves as the primary protein source in the human diet. Wheat provides approximately $18 \%$ of the calories and $20 \%$ of the proteins consumed by humans worldwide (FAOSTAT 2021). Therefore, grain yield (GY) and grain protein content (GPC) are critical traits to be considered for wheat breeding and production. Population growth and improvements in living conditions have necessitated an increase in wheat GY and GPC.

Nitrogen applications during wheat production are vital for increasing the GY and GPC ( Kichey et al. 2006; Zhang et al. 2012;Zheng et al. 2018). To produce wheat with a high GY and GPC, farmers tend to apply large amounts of nitrogen fertilizer to wheat fields, which increases cultivation costs and environmental pollution. Breeding to increase the wheat GY and GPC remains a considerable challenge because of the confirmed negative relationship between the two parameters (Laidig et al. 2017; Mirosavljevic et al. 2020; Subira et al. 2014; Tabbita et al. 2017). 
Wheat flour has unique processing properties that enable it to be used to make diverse end-products. The end-use quality of wheat is significantly influenced by the GPC. The unique processing quality of wheat flour depends on the seed storage proteins, but especially gliadins and glutenins, which combine to account for $60-80 \%$ of the total GPC (Rasheed et al. 2014; Shewry 2009). Gliadins are monomeric compounds that contribute to dough extensibility (Qi et al. 2006), whereas glutenins, which are polymeric compounds linked by intermolecular disulfide bonds, affect dough elasticity. Glutenins consist of high and low molecular weight glutenin subunits (Payne 1987; Wieser 2007).

Because the $Q$ gene influences many important traits, including GY and GPC, it plays a major role in wheat domestication and de-domestication (Jiang et al. 2019; Simons et al. 2006; Xie et al. 2018; Xu et al. 2018). This gene is located on the long arm of chromosome $5 \mathrm{~A}$ and encodes a member of the APETALA2 $\left(\mathrm{AP}_{2}\right)$ transcription factor family (Endo and Gill 1996; Simons et al. 2006). The $Q$ allele originated from a spontaneous mutation to the microRNA172-binding region of the $q$ allele (Simons et al. 2006). Similarly, the introduction of another point mutation in the microRNA172-binding site of the $Q$ allele resulted in the $Q^{c 1}$ allele (Xu et al. 2018). The $q, Q$, and $Q^{c 1}$ transcription levels are correlated with the number of point mutations in the microRNA172-binding site (Simons et al., 2006; Xu et al. 2018). Compared with the effects of the $Q$ allele, $Q^{c 1}$ increases the GPC by approximately $60 \mathrm{~g} \mathrm{~kg}^{-1}$, reflecting the value of $Q^{c 1}$ for wheat breeding. However, $Q^{c 1}$ decreases the longitudinal cell size of rachises, resulting in compact spikes and decreases in the GY (Xu et al. 2018). Missense mutations in the $Q$ sequence encoding the $\mathrm{AP}_{2}$ domain can lead to decreased spike density (Greenwood et al. 2017; Simons et al. 2006). Therefore, identifying or generating new $Q$ alleles that positively affect GY and GPC is warranted.

In this study, we characterized two new $Q$ alleles, namely $Q^{s 1}$ and $Q^{c 1}-N 8$, which have a single missense mutation in the sequences encoding the first and second $\mathrm{AP}_{2}$ domains, respectively. They were obtained via the chemical treatment of common wheat lines carrying the $Q$ and $Q^{c 1}$ alleles, respectively. The effects of $Q^{s 1}$ and $Q^{c 1}-N 8$ on the wheat GY and GPC were investigated.

\section{Materials And Methods}

Plant materials and growth conditions

The seeds of common wheat cultivar 'Shumai482' ( $Q$ allele) and its compact-spike mutant S-Cp1-1 ( $Q^{c 1}$ allele; Xu et al. 2018) were respectively treated with $0.8 \%$ and $0.4 \%$ ethyl methanesulfonate (SigmaAldrich, St Louis, MO, USA). Seeds from the leading spikes of the $M_{1}$ plants were harvested and sown to generate the $M_{2}$ population. The mutant SS1 (sparse spike 1) was obtained from the $M_{2}$ population of 'Shumai482'. The mutant NS8 (normal spike 8) was isolated from the $\mathrm{M}_{2}$ population of $S-C p 1-1$. The $Q$ genes of $S S 1$ ( $Q^{s 1}$ allele) and $N S 8\left(Q^{c 1}-N 8\right.$ allele) were sequenced.

The mutants were backcrossed with 'Shumai482' to assess the effects of $Q^{s 1}$ and $Q^{c 1}-N 8$ on agronomic traits and processing quality parameters. Ten $\mathrm{BC}_{2} \mathrm{~F}_{3}$ homozygous lines (five with the $Q$ allele and five with 
the $Q^{s 1}$ allele) and $10 \mathrm{BC}_{2} \mathrm{~F}_{4}$ homozygous lines (five with the $Q$ allele and five with the $Q^{s 1}$ allele) (Fig. 1) were grown at the experimental farm of Sichuan Agricultural University in Wenjiang $\left(30^{\circ} 43^{\prime} 16^{\prime \prime} \mathrm{N}\right.$, $103^{\circ} 52^{\prime} 15^{\prime \prime} \mathrm{E}$ ) during the 2018-2019 and 2019-2020 wheat growing seasons, respectively. Field trials were performed using a randomized block design. Each line was cultivated in a $2 \mathrm{~m} \times 3 \mathrm{~m}$ area, with a row spacing of $20 \mathrm{~cm} \times 5 \mathrm{~cm}$. The $\mathrm{BC}_{1} \mathrm{~F}_{2}$ plants carrying $Q$ or $Q^{c 1}-\mathrm{N} 8$ (Fig. 1) were grown with a row spacing of $20 \mathrm{~cm} \times 10 \mathrm{~cm}$ in Wenjiang during the 2020-2021 growing season. A nitrogen:phosphorous:potassium (15:15:15) compound fertilizer was applied before sowing (450 kg per hectare).

At the GS87 growth stage (Zadoks et al. 1974), agronomic traits, including plant height (cm), main spike length $(\mathrm{cm})$, spikelet number per main spike, grain number per main spike, and productive tiller number, were recorded. Spike density was calculated as the ratio of the main spike length to the spikelet number per main spike. For the $\mathrm{BC}_{2} \mathrm{~F}_{3}$ and $\mathrm{BC}_{2} \mathrm{~F}_{4}$ homozygous lines with the $Q$ or $Q^{s 1}$ allele, 20 representative plants of each line were examined. For the $\mathrm{BC}_{1} \mathrm{~F}_{2}$ plants carrying the $Q$ or $Q^{c 1}-N 8$ allele, the agronomic traits of each plant were evaluated.

After harvesting samples and drying under the sun at approximately $35^{\circ} \mathrm{C}$ to a constant weight, the thousand kernel weight $(\mathrm{g})$, grain length $(\mathrm{mm})$, and grain width $(\mathrm{mm})$ were determined. For each $\mathrm{BC}_{2} \mathrm{~F}_{3}$ and $\mathrm{BC}_{2} \mathrm{~F}_{4}$ homozygous line with the $Q$ or $Q^{s 1}$ allele, the thousand kernel weight was measured by randomly selecting 1,000 seeds. For the $\mathrm{BC}_{1} \mathrm{~F}_{2}$ plants carrying the $Q$ or $Q^{c 1}-N 8$ allele, the thousand kernel weight was measured on the basis of 200 randomly selected mature seeds. To measure the grain length and width, 100 randomly selected seeds were scanned using the Epson Eu-88 A3 Transparency Unit (Seiko Epson, Nagano, Japan). The resulting images were analyzed using the WinSEEDLE Analysis System (Regent Instruments, Quebec, Canada).

Gene cloning

Young leaves collected from individual plants at the GS13 growth stage (Zadoks et al. 1974) were ground to a fine powder in liquid nitrogen. Genomic DNA and total RNA were extracted from the ground materials using Plant DNA/RNA extraction kits, respectively (Biofit, Chengdu, China). First-strand cDNA was synthesized using the Prime Script ${ }^{\mathrm{TM}}$ 1st Strand cDNA Synthesis Kit (Takara, Dalian, China). All kits were used as recommended by the manufacturers.

The $Q$ cDNA and genomic DNA sequences of the mutants $S S 1$ and NS8 were cloned and sequenced. The PCR amplifications were completed in a $50 \mu \mathrm{L}$ volume consisting of genomic DNA or cDNA, $200 \mu \mathrm{M}$ dNTPs, $10 \mu \mathrm{M}$ each primer, 1 U Phanta Max Super-Fidelity DNA Polymerase (Vazyme, Nanjing, China), and $25 \mu \mathrm{L} 2 \times$ supplied buffer (with $\mathrm{Mg}^{2+}$ ). The PCR was performed using the Mastercycler Pro thermal cycler (Eppendorf, Hamburg, Germany) with the following program: $95^{\circ} \mathrm{C}$ for $5 \mathrm{~min} ; 35$ cycles of $95^{\circ} \mathrm{C}$ for $45 \mathrm{~s}, 60-68^{\circ} \mathrm{C}$ for $30 \mathrm{~s}$, and $72^{\circ} \mathrm{C}$ for $2 \mathrm{~min} ; 10 \mathrm{~min}$ at $72^{\circ} \mathrm{C}$. The PCR products were separated on a $1.5 \%$ agarose gel. The target fragments were purified using the FastPure Gel DNA Extraction Mini Kit (Vazyme) 
and then inserted into the pCE2 TA/Blunt-Zero vector using the 5 min TA/Blunt-Zero Cloning Kit (Vazyme). Positive colonies were sequenced by Sangon Biotech (Chengdu, China). The cloning and sequencing experiments were repeated at least three times. Sequences were analyzed using DNAMAN (version 8) (Lynnon Biosoft, San Ramon, USA). The primers used are listed in Table 1.

Table 1

Primers used in this study

\begin{tabular}{|c|c|c|c|}
\hline $\begin{array}{l}\text { Primers } \\
\text { name }\end{array}$ & Sequences $\left(5^{\prime}-3^{\prime}\right)$ & Reference & Objective \\
\hline AP2startF & ATGGTGCTGGATCTCAATGTGGAGTCGCCGGCGGA & $\begin{array}{l}\text { Simons } \\
\text { et al. } \\
2006\end{array}$ & \multirow{8}{*}{$\begin{array}{l}\text { Cloning of the } \\
\text { genomic DNA } \\
\text { sequence of } Q \\
\text { gene }\end{array}$} \\
\hline AP2.8R & CGCGGCCAAATCGGGGCAAAGGAATTCAAACGA & $\begin{array}{l}\text { Simons } \\
\text { et al. } \\
2006\end{array}$ & \\
\hline AP2.2-1F & ATCTTAGCTGTATGGGCTCGTG & $\begin{array}{l}\text { This } \\
\text { study }\end{array}$ & \\
\hline AP2.2-1R & TCAACGGAGATAGGGGTGTG & $\begin{array}{l}\text { This } \\
\text { study }\end{array}$ & \\
\hline AP2.2-2F & AGGCTCCACATAAGTATATGATCGAGTC & $\begin{array}{l}\text { This } \\
\text { study }\end{array}$ & \\
\hline AP2.2-2R & CTTAATTTCAGGAACGAACTTGTCG & $\begin{array}{l}\text { This } \\
\text { study }\end{array}$ & \\
\hline AP2.16F & CTGCTTGGTGCGCTGCTCCACCAGCTTACTGAAA & $\begin{array}{l}\text { Simons } \\
\text { et al. } \\
2006\end{array}$ & \\
\hline AP45.1R & CAGAAGGCCCAACGGTTAACGCAACAATGGC & $\begin{array}{l}\text { Simons } \\
\text { et al. } \\
2006\end{array}$ & \\
\hline $\begin{array}{l}\text { Q-mRNA- } \\
\text { F2-123 }\end{array}$ & TCGGAGATGGTGCTGGAT & $\begin{array}{l}\text { This } \\
\text { study }\end{array}$ & \multirow{2}{*}{$\begin{array}{l}\text { Cloning the full } \\
\text { open reading } \\
\text { frame of } Q \text { gene }\end{array}$} \\
\hline $\begin{array}{l}\text { Q-mRNA- } \\
\text { R1-1479 }\end{array}$ & GCCAGCTTCAGTTGTCCG & $\begin{array}{l}\text { This } \\
\text { study }\end{array}$ & \\
\hline QF5 & GCTTGCTTAGTTGTAGTACC & $\begin{array}{l}\text { This } \\
\text { study }\end{array}$ & \multirow[t]{2}{*}{$\begin{array}{l}\text { Genotyping of } Q^{c 1} \text { - } \\
N 8 \text { allele }\end{array}$} \\
\hline QR3 & CCTGGCAATGTCATCTCT & $\begin{array}{l}\text { This } \\
\text { study }\end{array}$ & \\
\hline
\end{tabular}

Genotyping for $Q^{c 1}-N 8$

Genomic DNA extracted from individual plants in the $\mathrm{BC}_{1} \mathrm{~F}_{2}$ population of the mutant $N S 8$ was used as the PCR template. The QF5 + QR3 primer pair (Table 1) flanking the microRNA172-binding site was used. 
The PCR amplifications were performed as described above. The PCR products were sequenced to determine the presence/absence of $Q^{c 1}-N 8$.

Processing quality analysis

Mature grains were dried under the sun, cleaned, and stored at room temperature for 2 months. After adjusting their moisture content to $16.5 \%$, the grain samples were milled using the CD1 Laboratory Mill (CHOPIN Technologies, Villeneuve-la-Garenne Cedex, France). The GPC (dry weight), Zeleny sedimentation value, wet gluten content, gluten index, and dough rheological properties were determined as described by Wang et al. (2021).

A baking test was performed according to a slightly modified version of AACC method 10.09-01 (AACC 2010). Specifically, a standard rapid mix test involving $50 \mathrm{~g}$ flour (14\% moisture content) was conducted. There were two loaves of bread per flour sample. The loaf volume was determined using the BVM6630 volume meter (Pertern, Stockholm, Sweden) as described by the manufacturer.

Statistical analysis

All data were calculated using Excel 2010 (Microsoft, Redmond, WA, USA). The significance of the differences in the mean values for the agronomic traits and processing quality parameters between the wild-type (WT) and mutant samples was determined according to Student's $t$-test implemented in the DPS (Data Processing System) software (version 18.10) (Zhejiang University, Hangzhou, China; Tang and Zhang 2013). The DPS software was also used to perform an analysis of variance.

\section{Results}

Phenotype of the mutant $S S 1$ carrying the $Q^{s 1}$ allele

To elevate the effect of missense mutations in the sequence encoding the $\mathrm{AP}_{2}$ domain of the $\mathrm{Q}$ protein, a mutant carrying the $Q^{s 1}$ allele (SS1) was isolated from the $\mathrm{M}_{2}$ population of the common wheat cultivar 'Shumai482'. The SS1 plants produced a speltoid-like spike (Fig. 2a). In contrast to the $Q$ allele (GenBank No. KX580301.2), $Q^{s 1}$ has a missense mutation (GenBank No. OK041024) in the sequence encoding the first $\mathrm{AP}_{2}$ domain (Figs. 3 and 4). Compared with the WT control (Fig. 1), SS1 plants were taller (Fig. 2b, Table 2) and had a longer main spike (Fig. 2a, Table 2), but a lower spike density (Table 2). 
Table 2

Comparison of the agronomic traits of the mutant SS1 and the wild-type (WT) control

\begin{tabular}{|c|c|c|c|c|c|c|}
\hline Traits & $\begin{array}{l}\text { Growing } \\
\text { season }\end{array}$ & SS1 & WT & $E$ & $\mathbf{G}$ & $E \times G$ \\
\hline \multirow[t]{3}{*}{ Plant height (cm) } & $2018-2019$ & \multirow{2}{*}{$\begin{array}{l}83.41 \pm \\
4.05^{\star \star}\end{array}$} & \multirow{2}{*}{$\begin{array}{l}79.44 \pm \\
3.09\end{array}$} & \multirow[t]{3}{*}{$205.087 \star \star$} & \multirow[t]{3}{*}{$24.459 * *$} & \multirow[t]{3}{*}{0.534} \\
\hline & \multirow[t]{2}{*}{$2019-2020$} & & & & & \\
\hline & & $\begin{array}{l}71.82 \pm \\
2.30 * \star\end{array}$ & $\begin{array}{l}67.11 \pm \\
2.00\end{array}$ & & & \\
\hline \multirow[t]{3}{*}{ Spike length (cm) } & \multirow{3}{*}{$\begin{array}{l}2018-2019 \\
2019-2020\end{array}$} & $14.65 \pm$ & $14.06 \pm$ & \multirow[t]{3}{*}{123.331 ** } & \multirow[t]{3}{*}{$15.408^{\star \star}$} & \multirow[t]{3}{*}{2.680} \\
\hline & & & & & & \\
\hline & & $\begin{array}{l}12.88 \pm \\
0.80^{* *}\end{array}$ & $\begin{array}{l}11.87 \pm \\
0.46\end{array}$ & & & \\
\hline \multirow{3}{*}{$\begin{array}{l}\text { Spikelet number per } \\
\text { main spike }\end{array}$} & $2018-2019$ & \multirow{2}{*}{$\begin{array}{l}21.00 \pm \\
1.15^{\star \star}\end{array}$} & \multirow{2}{*}{$\begin{array}{l}22.94 \pm \\
1.44\end{array}$} & \multirow[t]{3}{*}{$15.038^{* *}$} & \multirow[t]{3}{*}{$24.858 * \star$} & \multirow[t]{3}{*}{0.110} \\
\hline & \multirow[t]{2}{*}{$2019-2020$} & & & & & \\
\hline & & $\begin{array}{l}19.93 \pm \\
0.70^{\star \star}\end{array}$ & $\begin{array}{l}21.43 \pm \\
1.45\end{array}$ & & & \\
\hline \multirow[t]{3}{*}{ Spike density } & \multirow{3}{*}{$\begin{array}{l}2018-2019 \\
2019-2020\end{array}$} & $1.43 \pm$ & $1.63 \pm$ & \multirow[t]{3}{*}{$45.434^{\star \star}$} & \multirow[t]{3}{*}{$84.944 \star \star$} & \multirow[t]{3}{*}{13.78} \\
\hline & & 0.07 & & & & \\
\hline & & $\begin{array}{l}1.55 \pm \\
0.10^{\star \star}\end{array}$ & $\begin{array}{l}1.80 \pm \\
0.08\end{array}$ & & & \\
\hline \multirow[t]{3}{*}{$\begin{array}{l}\text { Grain number per main } \\
\text { spike }\end{array}$} & 2018-2019 & \multirow{2}{*}{$\begin{array}{l}58.81 \pm \\
5.83^{\star}\end{array}$} & \multirow{2}{*}{$\begin{array}{l}65.13 \pm \\
8.23\end{array}$} & \multirow[t]{3}{*}{$43.376^{\star \star}$} & \multirow[t]{3}{*}{$8.860 * \star$} & \multirow[t]{3}{*}{0.044} \\
\hline & \multirow[t]{2}{*}{$2019-2020$} & & & & & \\
\hline & & $4.14^{\star}$ & 4.25 & & & \\
\hline \multirow{3}{*}{$\begin{array}{l}\text { Thousand kernel } \\
\text { weight }(\mathrm{g})\end{array}$} & $2018-2019$ & \multirow{2}{*}{$\begin{array}{l}44.08 \pm \\
1.71^{*}\end{array}$} & \multirow{2}{*}{$\begin{array}{l}46.13 \pm \\
0.43\end{array}$} & \multirow[t]{3}{*}{$50.427 * \star$} & 13.780 ** & 0.216 \\
\hline & $2019-2020$ & & & & & \\
\hline & & $\begin{array}{l}48.76 \pm \\
1.25^{\star}\end{array}$ & $\begin{array}{l}51.90 \pm \\
1.67\end{array}$ & & & \\
\hline Tiller number & $2018-2019$ & $5.30 \pm 1.03$ & $5.25 \pm$ & 27.478 ** & 0.730 & 1.207 \\
\hline & $2019-2020$ & $3.85 \pm 0.74$ & & & & \\
\hline & & & $\begin{array}{l}4.25 \pm \\
0.79\end{array}$ & & & \\
\hline
\end{tabular}

Regarding the examined yield-related traits, the spikelet number per main spike, grain number per main spike, thousand kernel weight (Table 2), and grain width (Fig. 2c and e) were lower for SS1 than for the WT control. In contrast, the grain length (Fig. 2d and f) was greater for SS1 than for the WT control. Notably, there was no significant difference in the productive tiller number between the SS1 and WT plants (Table 2). Therefore, the GY was significantly lower $(P<0.01)$ for $S S 1\left(0.46 \mathrm{~kg} \mathrm{~m}^{-2}\right)$ than for the WT control $\left(0.58 \mathrm{~kg} \mathrm{~m}^{-2}\right)$ in the 2018-2019 growing season. Under our experimental conditions, the $Q^{s 1}$ 
allele decreased the GY by $20.6 \%$ by decreasing the thousand kernel weight and the grain number per spike.

An analysis of the processing quality traits revealed a lack of a significant difference between the SS1 and WT plants regarding the GPC, wet gluten content, gluten index, Zeleny sedimentation value, water absorption, development time, stable time, and loaf volume (Table 3; Fig. 5). 
Table 3

Comparison of the processing quality parameters of the mutant $S S 1$ and the wild-type (WT) control

\begin{tabular}{|c|c|c|c|c|c|c|}
\hline Trails & $\begin{array}{l}\text { Growing } \\
\text { season }\end{array}$ & SS1 & WT & $E$ & G & $E \times G$ \\
\hline \multirow{2}{*}{$\begin{array}{l}\text { Grain protein content (\%; } \\
\text { dry weight) }\end{array}$} & 2018-2019 & $\begin{array}{l}13.12 \pm \\
0.43\end{array}$ & $\begin{array}{l}13.45 \pm \\
0.36\end{array}$ & \multirow[t]{2}{*}{$30.313^{\star \star}$} & \multirow[t]{2}{*}{2.562} & \multirow[t]{2}{*}{0.323} \\
\hline & $2019-2020$ & $\begin{array}{l}14.53 \pm \\
0.60\end{array}$ & $\begin{array}{l}15.16 \pm \\
0.76\end{array}$ & & & \\
\hline \multirow{2}{*}{$\begin{array}{l}\text { Zeleny sedimentation } \\
\text { value }(\mathrm{mL})\end{array}$} & 2018-2019 & $\begin{array}{l}32.65 \pm \\
3.64\end{array}$ & $\begin{array}{l}27.73 \pm \\
4.20\end{array}$ & \multirow[t]{2}{*}{$29.114^{\star \star}$} & \multirow[t]{2}{*}{0.301} & \multirow[t]{2}{*}{4.315} \\
\hline & $2019-2020$ & $\begin{array}{l}21.54 \pm \\
2.51\end{array}$ & $\begin{array}{l}23.88 \pm \\
1.98\end{array}$ & & & \\
\hline \multirow[t]{2}{*}{ Wet gluten content (\%) } & 2018-2019 & $\begin{array}{l}24.72 \pm \\
1.60\end{array}$ & $\begin{array}{l}24.98 \pm \\
3.06\end{array}$ & \multirow[t]{2}{*}{$14.645^{\star \star}$} & \multirow[t]{2}{*}{0.570} & \multirow[t]{2}{*}{2.996} \\
\hline & $2019-2020$ & $\begin{array}{l}27.21 \pm \\
1.49\end{array}$ & $\begin{array}{l}29.66 \pm \\
2.05\end{array}$ & & & \\
\hline \multirow[t]{2}{*}{ Gluten index (\%) } & 2018-2019 & $\begin{array}{l}92.87 \pm \\
2.59\end{array}$ & $\begin{array}{l}87.32 \pm \\
8.94\end{array}$ & \multirow[t]{2}{*}{$65.599 * *$} & \multirow[t]{2}{*}{0.004} & \multirow[t]{2}{*}{0.315} \\
\hline & $2019-2020$ & $\begin{array}{l}63.37 \pm \\
9.02\end{array}$ & $\begin{array}{l}65.04 \pm \\
6.69\end{array}$ & & & \\
\hline \multirow[t]{2}{*}{ Water absorption (\%) } & 2018-2019 & $\begin{array}{l}50.36 \pm \\
0.71\end{array}$ & $\begin{array}{l}50.88 \pm \\
1.67\end{array}$ & \multirow[t]{2}{*}{$428.875^{\star \star}$} & \multirow[t]{2}{*}{0.783} & \multirow[t]{2}{*}{0.077} \\
\hline & $2019-2020$ & $\begin{array}{l}58.74 \pm \\
1.12\end{array}$ & $\begin{array}{l}58.28 \pm \\
0.45\end{array}$ & & & \\
\hline \multirow[t]{2}{*}{ Development time (s) } & 2018-2019 & $\begin{array}{l}78.00 \pm \\
13.22\end{array}$ & $\begin{array}{l}77.67 \pm \\
9.14\end{array}$ & $7.440 *$ & 0.365 & 2.875 \\
\hline & $2019-2020$ & $\begin{array}{l}61.50 \pm \\
10.71\end{array}$ & $\begin{array}{l}68.40 \pm \\
10.46\end{array}$ & & & \\
\hline Stable time (s) & $2018-2019$ & $260.86 \pm$ & $203.83 \pm$ & 0.394 & 0.125 & 1.560 \\
\hline & $2019-2020$ & $\begin{array}{l}193.20 \pm \\
56.34\end{array}$ & $\begin{array}{l}230.40 \pm \\
54.54\end{array}$ & & & \\
\hline
\end{tabular}

Characterization of the mutant $N S 8$ carrying the $Q^{c 1}-N 8$ allele

Because a missense mutation in the sequence encoding the $\mathrm{AP}_{2}$ domain can decrease the spike density without altering processing quality parameters, the normal-spike mutant $N S 8$ containing the $Q^{c 1}-N 8$ allele was isolated from the $\mathrm{M}_{2}$ population of the mutant S-Cp1-1. The NS8 plants had a normal spike, which was similar to the 'Shumai482' spike (Fig. 6a). Compared with the $Q$ allele sequence, $Q^{c 1}-N 8$ contains two 
missense mutations (GenBank No. OK041023), with one in the sequence encoding the second $\mathrm{AP}_{2}$ domain and the other in the microRNA172-binding region (Figs. 3 and 4). When compared with the WT control $\left(\mathrm{BC}_{1} \mathrm{~F}_{2}\right.$ plants with only the $Q$ allele; Fig. 1$)$, the mutant $N S 8$ plants were shorter (Figs. $6 \mathrm{~b}$ and $7 \mathrm{~b}$ ), but had a similar main spike length (Figs. 6a and 7d) and spike density (Fig. 7f).

Of the yield-related traits, the grain number per main spike (Fig. 7a), thousand kernel weight (Fig. 6e), grain width (Fig. 6d and g), and grain length (Fig. $6 \mathrm{c}$ and $\mathrm{h}$ ) were greater for the mutant NS8 than for the WT control. However, there were no significant differences in the spikelet number per main spike (Fig. 7e) and productive tiller number (Fig. 7c) between the NS8 and WT plants. As expected, the $Q^{C 1}{ }^{-N 8}$ allele positively affected the GPC (Fig. 6f) and GY by increasing the thousand kernel weight and grain number per spike.

\section{Discussion}

Because GY and GPC determine the profitability of wheat production, they are the primary traits wheat breeders and growers focus on. More specifically, GY is critical for ensuring food security, especially in many developing countries, whereas GPC is a crucial index for assessing the nutritional and unique processing quality of wheat (Weegels et al. 1996). Both traits are very important for improving the living standards of humans. Therefore, there is an urgent need for increasing the wheat GY and GPC. As an essential macronutrient for plants, nitrogen is crucial for establishing a balance between GY and GPC during wheat production (Masoni et al. 2007; Zhang et al. 2012; Zheng et al. 2018). Consequently, the most frequent cultivation practice used by farmers to increase the GY and GPC is the application of nitrogen fertilizers (Barneix 2007; Zheng et al. 2018), but this leads to increased cultivation costs, decreased nitrogen use efficiency, and increased environmental pollution. Moreover, after incremental additions of nitrogen fertilizer, the GPC reaches a maximum and then remains constant (Barneix 2007). In this study, we created a new $Q$ allele (i.e., $Q^{c 1}-N 8$ ), which breaks the negative relationship between $G Y$ and GPC and can synchronously increase the wheat GY and GPC. Thus, $Q^{c 1}-N 8$ may be useful for breeding more profitable wheat varieties.

'Shumai482' is an elite commercial wheat cultivar with a relatively high GY and GPC. The $Q^{c 1}-N 8$ allele can increase both GY and GPC in the 'Shumai482' genetic background. Specifically, this allele was associated with a GPC increase of approximately $21 \mathrm{~g} \mathrm{~kg}^{-1}$ (16.0\%; Fig. 6f), a thousand kernel weight increase of about $3.9 \mathrm{~g}(8.1 \%$; Fig. $6 \mathrm{e})$, and a grain number per main spike increase of approximately 7.1 (13.2\%; Fig. 7a). Notably, $Q^{c 1}-N 8$ decreased the plant height by about $5.1 \mathrm{~cm}(7.6 \%$; Fig. 7b), thereby enhancing lodging resistance. Lodging is still a major factor limiting global wheat production, especially in regions with heavy rain and strong winds, because it leads to serious decreases in the GY. We are currently assessing the breeding value of $Q^{c 7}-N 8$ in multiple environments, in diverse genetic backgrounds, and in field plot experiments. 
Modifying the amino acids in the $\mathrm{AP}_{2}$ domains of the $\mathrm{Q}$ protein may reverse the unfavorable agronomic traits of the mutant $S$ - $C P 1-1$ carrying the $Q^{c 1}$ allele (Xu et al. 2018). The mutation in the $Q^{s 1}$ allele results in a single amino acid change in the first $\mathrm{AP}_{2}$ domain (Figs. 3 and 4), which negatively affects the thousand kernel weight (Table 2). The overexpressed $Q^{c 1}$ allele has a missense mutation in the mircoRNA172-binding site (Figs. 3 and 4) that increases the thousand kernel weight (Xu et al. 2018). It is likely that at least some missense mutations in the sequences encoding the $\mathrm{AP}_{2}$ domains and those in the microRNA172-binding site have the opposite effect on the thousand kernel weight. The $Q^{c 1}{ }_{-} N 8$ allele has two missense mutations, with one in the sequence encoding the $\mathrm{AP}_{2}$ domain and the other in the microRNA172-binding site (Figs. 3 and 4); this allele is associated with an increase in the thousand kernel weight (Fig. 6E). Therefore, the opposite effects of the two point mutations in the $Q^{c 1}-N 8$ allele are relatively well balanced to increase the thousand kernel weight. However, further increases in the GY require the creation of new alleles with mutation(s) beyond the $\mathrm{AP}_{2}$ domain-encoding sequences; four previously reported $Q^{c}$ alleles (i.e., $Q^{c 1}-Q^{c 4}$; Xu et al. 2018) may be useful for generating new alleles.

Common wheat is a hexaploid species (AABBDD; $2 n=6 x=42$ ) that contains three homologous genomes (i.e., A, B, and D). An earlier study revealed the dosage effect of the $Q$ gene in wheat (Muramatsu 1963). To date, only the $Q$ gene copy in the A genome has been optimized. To further improve the GY and GPC, the stepwise optimization of the $Q$ copies in the B and $\mathrm{D}$ genomes of common wheat and related species is ongoing.

Durum wheat (Triticum turgidum ssp. durum) is a tetraploid species (AABB; $2 n=4 x=28$ ), and is the main and preferred raw material for pasta production (Sissons 2008). The GPC is a determining factor influencing durum wheat quality, and grains with a high GPC tend to produce good cooking quality pasta (Porceddu et al. 1998; Sissons 2008; Walsh and Gilles 1971). The $Q^{c 1}-N 8$ allele, which is located in the A genome, may be useful for durum wheat breeding.

In addition to the $Q$ gene, many other plant genes include microRNA-binding sites, including some genes encoding a conserved $\mathrm{AP}_{2}$ domain. The directed evolution of these genes via the introduction of point mutations in their microRNA-binding sites and other domain-encoding sequences may be an efficient and effective way to ensure world food security.

Increases in the GY and GPC are also required for other major cereal crops, such as rice, maize, barley, sorghum, and foxtail millet, which carry $Q$ gene orthologs and homologs (Chuck et al. 2008; Dong et al. 2019; Gil-Humanes et al. 2009; Lee and An 2012; Solomon and Drea 2019; Wang et al. 2019). Moreover, these orthologous and homologous genes seem to have conserved functions among cereals (Dong et al. 2019; Lee and An 2012; Wang et al. 2019). Similar to the allele development in this study (i.e., $Q$ allele to $Q^{c 1}$ and then to $Q^{c 1}-N 8$ ), elite alleles for the $Q$ gene orthologs and homologs can be created by the stepwise optimization of their expression (e.g., by introducing point mutations in the mircoRNA172binding site or in other elements) and by enhancing the activities of the encoded proteins (e.g., by introducing point mutations in the sequences encoding the $\mathrm{AP}_{2}$ domains or other domains) affecting 
specific downstream gene(s) and interacting protein(s). Therefore, increasing the GY and GPC of cereal crops by creating a set of elite alleles of the $Q$ gene orthologs and homologs in breeding programs involving non-transgenic methods is a viable strategy.

\section{Declarations}

\section{Funding}

This study was supported by the National Natural Science Foundation of China (grant numbers 32072054, 31971939, and 31671677), the Science and Technology Department of Sichuan Province (2019YFH0066, and 20GJHZ0048).

\section{Conflicts of interest}

The authors declare no conflict of interest.

\section{Availability of data and material}

The wheat mutants are available upon request for wheat breeding.

Code availabilityNot applicable

\section{Author' contributions}

$P Q$ designed the experiments and prepared the plant materials. QC and $P Q$ wrote the manuscript. $Q C, Z G$, $X S, M W, Y F, J Z, T Z, Y W, L K, M D, X C, J W, Y W, Q J, Y J, G C, Y Z$ and $P Q$ conducted the experiments, analyzed the data, prepared the figures, and provided key advice.

Ethics approval Not applicable

Consent to participate Not applicable

Consent for publication Not applicable

Plant voucher number and consent for field experiments Not applicable.

\section{Acknowledgment}

We thank Liwen Bianji (Edanz) (www.liwenbianji.cn/) for editing the English text of a draft of this manuscript.

\section{References}

1. AACC International (2010) Basic straight-dough bread-baking method - long fermentation (Method 10-09.01). Cereals \& Grains Association, St. Paul. http://methods.aaccnet.org/ 
2. Barnex AJ (2007) Physiology and biochemistry of source-regulated protein accumulation in the wheat grain. J Plant Physiol 164:581-590. https://doi.org/10.1016/j.jplph.2006.03.009

3. Chuck G, Meeley R, Hake S (2008) Floral meristem initiation and meristem cell fate are regulated by the maize AP2 genes ids1 and sid1. Development 135:3013-3019. https://doi.org/10.1242/dev.024273

4. Dong Z, Alexander M, Chuck G (2019) Understanding grass domestication through maize mutants. Trends Genet 35:118-128. https://doi.org/10.1016/j.tig.2018.10.007

5. Endo TR, Gill BS (1996) The deletion stocks of common wheat. J Hered 87:295-307. https://doi.org/10.1093/oxfordjournals.jhered.a023003

6. FAOSTAT (2021) FAO Database. Food and Agriculture Organization of the United Nations. http://www.fao.org/faostat/en/\#data. Accessed 26 July 2021

7. Gil-Humanes J, Piston F, Martin A, Barro F (2009) Comparative genomic analysis and expression of the APETALA2-like genes from barley, wheat, and barley-wheat amphiploids. BMC Plant Biol 9:66. https://doi.org/10.1186/1471-2229-9-66

8. Greenwood JR, Finnegan EJ, Watanabe N, Trevaskis B, Swain SM (2017) New alleles of the wheat domestication gene $Q$ reveal multiple roles in growth and reproductive development. Development 144:1959-1965. https://doi.org/10.1242/dev.146407

9. Jiang YF, Chen Q, Wang Y, Guo ZR, Xu BJ, Zhu J, Zhang YZ, Gong X, Luo CH, Wu W, Liu CH, Kong L, Deng M, Jiang QT, Lan XJ, Wang JR, Chen GY, Zheng YL, Wei YM, Qi PF (2019) Re-acquisition of the brittle rachis trait via a transposon insertion in domestication gene $Q$ during wheat de-domestication. New Phytol 224:961-973. https://doi.org/10.1111/nph.15977

10. Kichey T, Heumez E, Pocholle D, Pageau K, Vanacker H, Dubois F, Le Gouis J, Hirel B (2006) Combined agronomic and physiological aspects of nitrogen management in wheat highlight a central role for glutamine synthetase. New Phytol 169:265-278. https://doi.org/10.1111/j.14698137.2005.01606.x

11. Laidig F, Piepho HP, Dirk Rentel D, Thomas Drobek T, Meyer U, Huesken A (2017) Breeding progress, environmental variation and correlation of winter wheat yield and quality traits in German official variety trials and onfarm during 1983-2014. Theor Appl Genet 130:223-245. https://doi.org/10.1007/s00122-016-2810-3

12. Lee D, An G (2012) Two AP2 family genes, SUPERNUMERARY BRACT (SNB) and OsINDETERMINATE SPIKELET 1 (OSIDS1), synergistically control inflorescence architecture and floral meristem establishment in rice. Plant J 69:445-461. https://doi.org/10.1111/j.1365-313X.2011.04804.x

13. Masoni A, Ercoli L, Mariotti M, Arduini I (2007) Post-anthesis accumulation and remobilization of dry matter, nitrogen and phosphorus in durum wheat as affected by soil type. Eur J Agron 26:179-186. https://doi.org/10.1016/j.eja.2006.09.006

14. Mirosavljevic M, Momcilovic V, Zivancev D, Acin V, Jockovic B, Mikic S, Takac V, Dencic S (2020) Genetic improvement of grain yield and bread-making quality of winter wheat over the past 90 years 
under the Pannonian Plain conditions. Euphytica 216:184. https://doi.org/10.1007/s10681-02002724-5

15. Muramatsu M (1963) Dosage effect of the spelta gene $q$ of hexaploid wheat. Genetics 48:469-482

16. Payne PI (1987) Genetics of wheat storage proteins and the effect of allelic variation on breadmaking quality. Ann Rev Plant Physiol 38:141-153.

https://doi.org/10.1146/annurev.pp.38.060187.001041

17. Porceddu E, Turchetta T, Masci S, D'Ovidio R, Lafiandra D, Kasarda DD, Impiglia A, Nachit MM (1998) Variation in endosperm protein composition and technological quality properties in durum wheat. Euphytica 100:197-205. https://doi.org/10.1023/A:1018338308795

18. Qi PF, Wei YM, Yue YW, Yan ZH, Zheng YL (2006) Biochemical and molecular characterization of gliadins. Mol Biol 40:713-723. https://doi.org/10.1134/S0026893306050050

19. Rasheed A, Xia X, Yan Y, Appels R, Mahmood T, He Z (2014) Wheat seed storage proteins: Advances in molecular genetics, diversity and breeding applications. J Cereal Sci 60:11-24. https://doi.org/10.1016/j.jcs.2014.01.020

20. Shewry PR (2009) Wheat. J Exp Bot 60:1537-1553. http://dx.doi.org/10.1093/jxb/erp058

21. Simons KJ, Fellers JP, Trick HN, Zhang Z, Tai Y, Gill BS, Faris JD (2006) Molecular characterization of the major wheat domestication gene $Q$. Genetics 172:547-555.

https://doi.org/10.1534/genetics.105.044727

22. Sissons M (2008) Role of durum wheat composition on the quality of pasta and bread. Food 2:7590

23. Solomon CS, Drea S (2019) Besides and beyond flowering: other roles of EUAP2 genes in plant development. Genes 10:994. https://doi.org/10.3390/genes10120994

24. Subira J, Peña RJ, Álvaro F, Ammar K, Ramdani A, Royo C (2014) Breeding progress in the pastamaking quality of durum wheat cultivars released in Italy and Spain during the 20th Century. Crop Pasture Sci 65:16-26. https://doi.org/10.1071/CP13238

25. Tabbita F, Pearce S, Barneix AJ (2017) Breeding for increased grain protein and micronutrient content in wheat: Ten years of the GPC-B1 gene. J Cereal Sci 73:183-191.

https://doi.org/10.1016/j.jcs.2017.01.003

26. Tang QY, Zhang CX (2013) Data Processing System (DPS) software with experimental design, statistical analysis and data mining developed for use in entomological research. Insect Sci 20:254260. https://doi.org/10.1111/j.1744-7917.2012.01519.x

27. Walsh DE, Gilles KA (1971) The influence of protein composition on spaghetti quality. Cereal Chem 48:544-553

28. Wang J, Lin Z, Zhang X, Liu H, Zhou L, Zhong S, Li Y, Zhu C, Lin Z (2019) krn1, a major quantitative trait locus for kernel row number in maize. New Phytol 223:1634-1646.

https://doi.org/10.1111/nph.15890 
29. Wang Y, Chen Q, Li Y, Guo ZR, Liu CH, Wan YF, Hawkesford M, Zhu J, Wu W, Wei MQ, Zhao K, Jiang YF, Zhang YZ, Xu Q, Kong L, Pu ZE, Deng M, Jiang QT, Lan XJ, Wang JR, Chen GY, Ma J, Zheng YL, Wei YM, Qi PF (2021) Post-translational cleavage of HMW-GS Dy10 allele improves the cookiemaking quality in common wheat (Triticum aestivum). Mol Breeding 41:49. https://doi.org/10.1007/s11032-021-01238-9

30. Weegels PL, Hamer RJ, Schofield JD (1996) Functional properties of wheat glutenin. J Cereal Sci 23:1-18. https://doi.org/10.1006/jcrs.1996.0001

31. Wieser H (2007) Chemistry of gluten proteins. Food Microbiol 24:115-119. https://doi.org/10.1016/j.fm.2006.07.004

32. Xie Q, Li N, Yang Y, Lv L, Yao H, Wei R, Sparkes DL, Ma ZQ (2018) Pleiotropic effects of the wheat domestication gene $Q$ on yield and grain morphology. Planta 247:1089-1098. https://doi.org/10.1007/s00425-018-2847-4

33. Xu BJ, Chen Q, Zheng T, Jiang YF, Qiao YY, Guo ZR, Cao YL, Wang Y, Zhang YZ, Zong LJ, Zhu J, Liu CH, Jiang QT, Lan XJ, Ma J, Wang JR, Zheng YL, Wei YM, Qi PF (2018) An overexpressed Q allele leads to increased spike density and improved processing quality. Genes Genom Genet G3:8:771778. https://doi.org/10.1534/g3.117.300562

34. Zadoks JC, Chang TT, Konzak CF (1974) A decimal code for the growth stages of cereals. Weed Res 14:415-421. https://doi.org/10.1111/j.1365-3180.1974.tb01084.x

35. Zhang Y, Zhang Y, Liu N, Su D, Xue Q, Stewart BA, Wang Z (2012) Effect of source-sink manipulation on accumulation of micronutrients and protein in wheat grains. J Plant Nutr Soil Sci 175:622-629. https://doi.org/10.1002/jpln.201100224

36. Zhang Z, Belcram H, Gornicki P, Charles M, Just J, Huneau C, Magdelenat G, Couloux A, Samain S, Gill BS, Rasmussen JB, Barbe V, Faris JD, Chalhoub B (2011) Duplication and partitioning in evolution and function of homoeologous $Q$ loci governing domestication characters in polyploid wheat. PNAS USA 108:18737-18742. https://doi.org/10.1073/pnas.1110552108

37. Zheng T, Qi PF, Cao YL, Han YN, Ma HL, Guo ZR, Wang Y, Qiao YY, Hua SY, Yu HY, Wang JP, Zhu J, Zhou CY, Zhang YZ, Chen Q, Kong L, Wang JR, Jiang QT, Yan ZH, Lan XJ, Fan GQ, Wei YM, Zheng YL (2018) Mechanisms of wheat (Triticum aestivum) grain storage proteins in response to nitrogen applications and its impacts on processing quality. Sci Rep 8:11928. https://doi.org/10.1038/s41598-018-30451-4

\section{Figures}




\section{Shumai 482 ( $Q$ allele)}

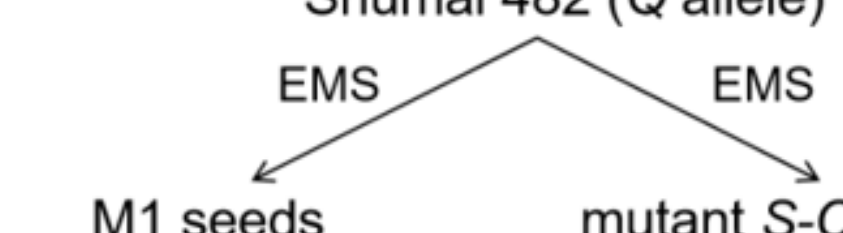

M1 seeds

$\downarrow \otimes$

mutant SS1 $\left(\mathrm{M}_{2}\right)$

$\downarrow \otimes$ mutant S-Cp1-1 ( $Q^{c 1}$ allele)

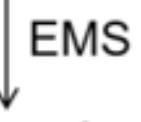

$M_{1}$ seeds

$\downarrow \otimes$

mutant NS8 $\left(\mathrm{M}_{2}\right)$

$\downarrow \otimes$

Shumai $482 \times$ mutant $N S 8\left(\mathrm{M}_{5}\right)$

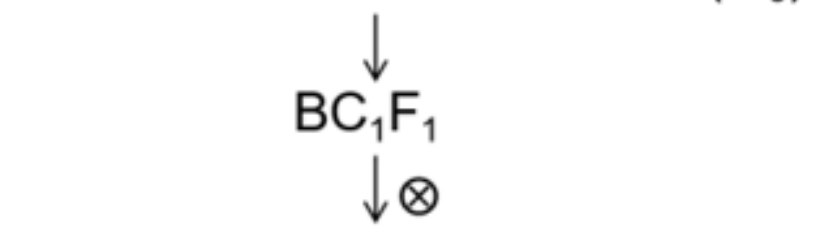

single plant

$\mathrm{BC}_{2} \mathrm{~F}_{3}$

(WT) (mutant SS1)

$Q$ allele $\quad Q^{s 1}$ allele

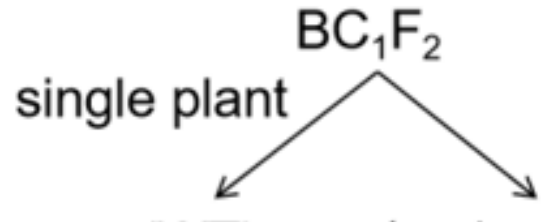

(WT) (mutant NS8)

$Q$ allele $\quad Q^{c 1}-N 8$ allele

\section{Figure 1}

Outline of the generation of the mutants SS1 and NS8 in the T. aestivum cv. 'Shumai 482' genetic background 
a

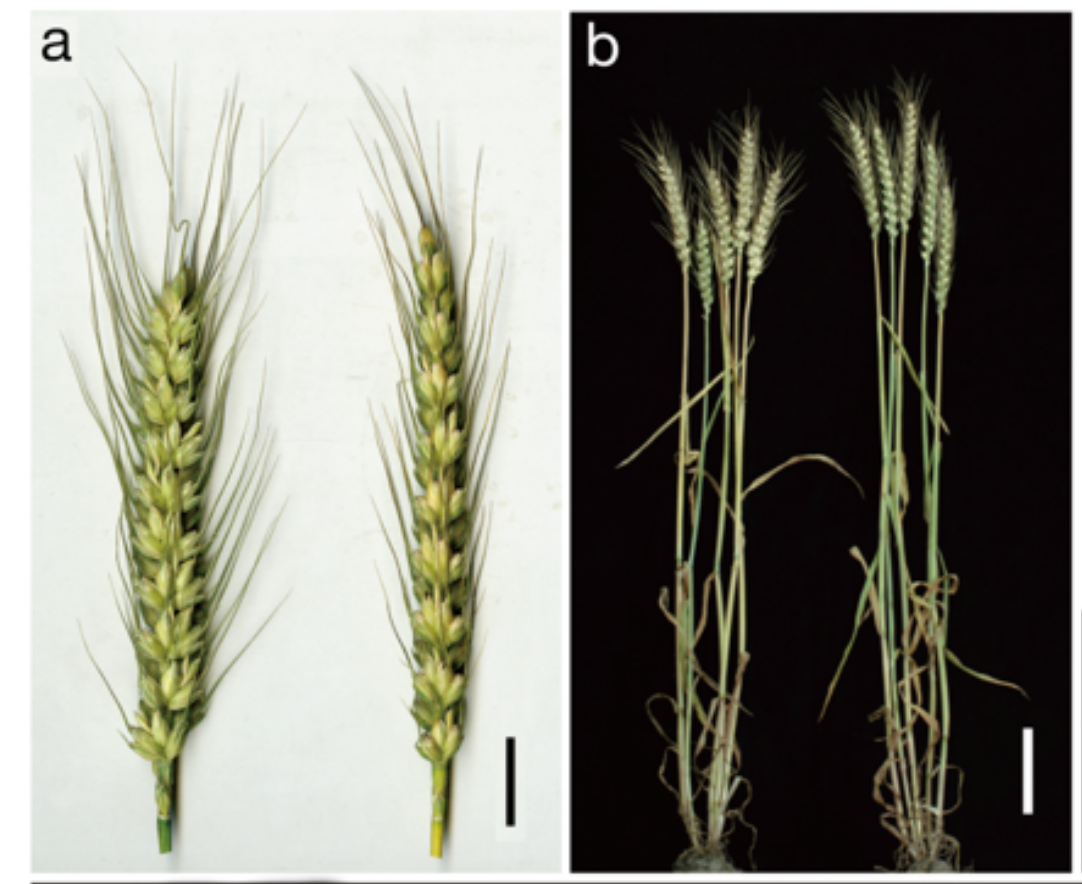

\section{b}

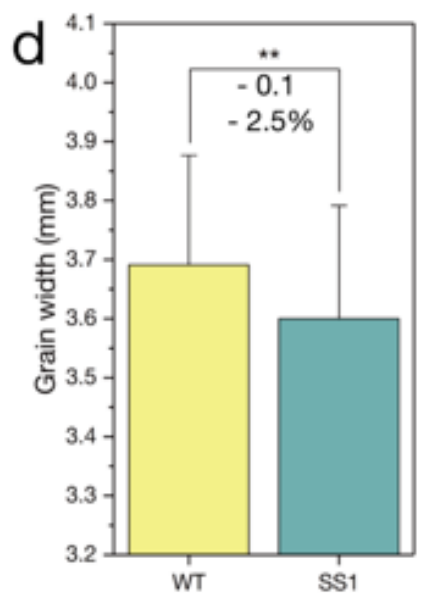

e

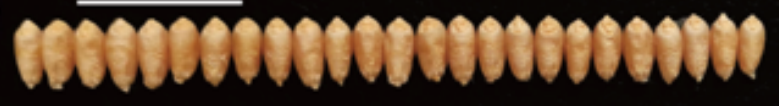
ammenanomonomongen

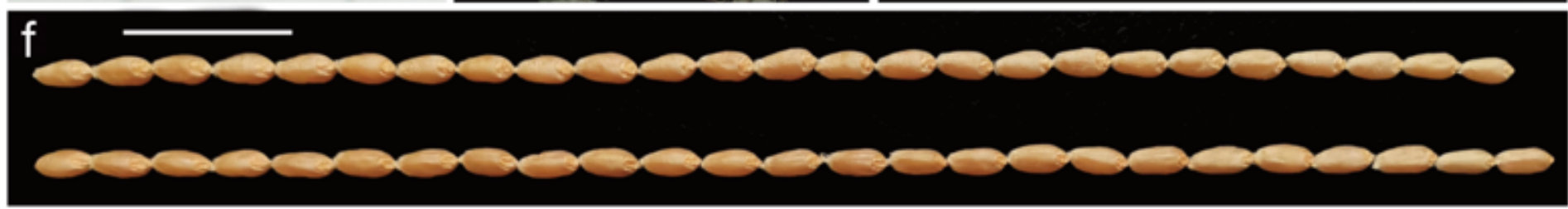

Figure 2

Phenotype of the mutant SS1. (a) Spikes of the wild-type (WT) (left) and NS8 (right) plants. Scale bar, 2 $\mathrm{cm}$. (b) WT (left) and NS8 (right) plants. Scale bar, $10 \mathrm{~cm}$. Comparisons of grain length (c) and grain width (d). **, $P<0.01 ; *, P<0.05$. Data are presented as the mean \pm standard deviation. ' + ' and ' - ' indicate more and less than the WT control, respectively. ' +0.2 ' in panel (c) indicates the NS8 grain was $0.2 \mathrm{~mm}$ longer than the WT grain (on average). ' $+2.6 \%$ ' in panel (c) indicates Qs1 increased the grain length by $2.6 \%$ (on average). (e) Kernel width of the WT (upper) and SS1 (lower) samples. Scale bar, $2 \mathrm{~cm}$. (f) Kernel length of the WT (upper) and SS1 (lower) samples. Scale bar, $2 \mathrm{~cm}$ 


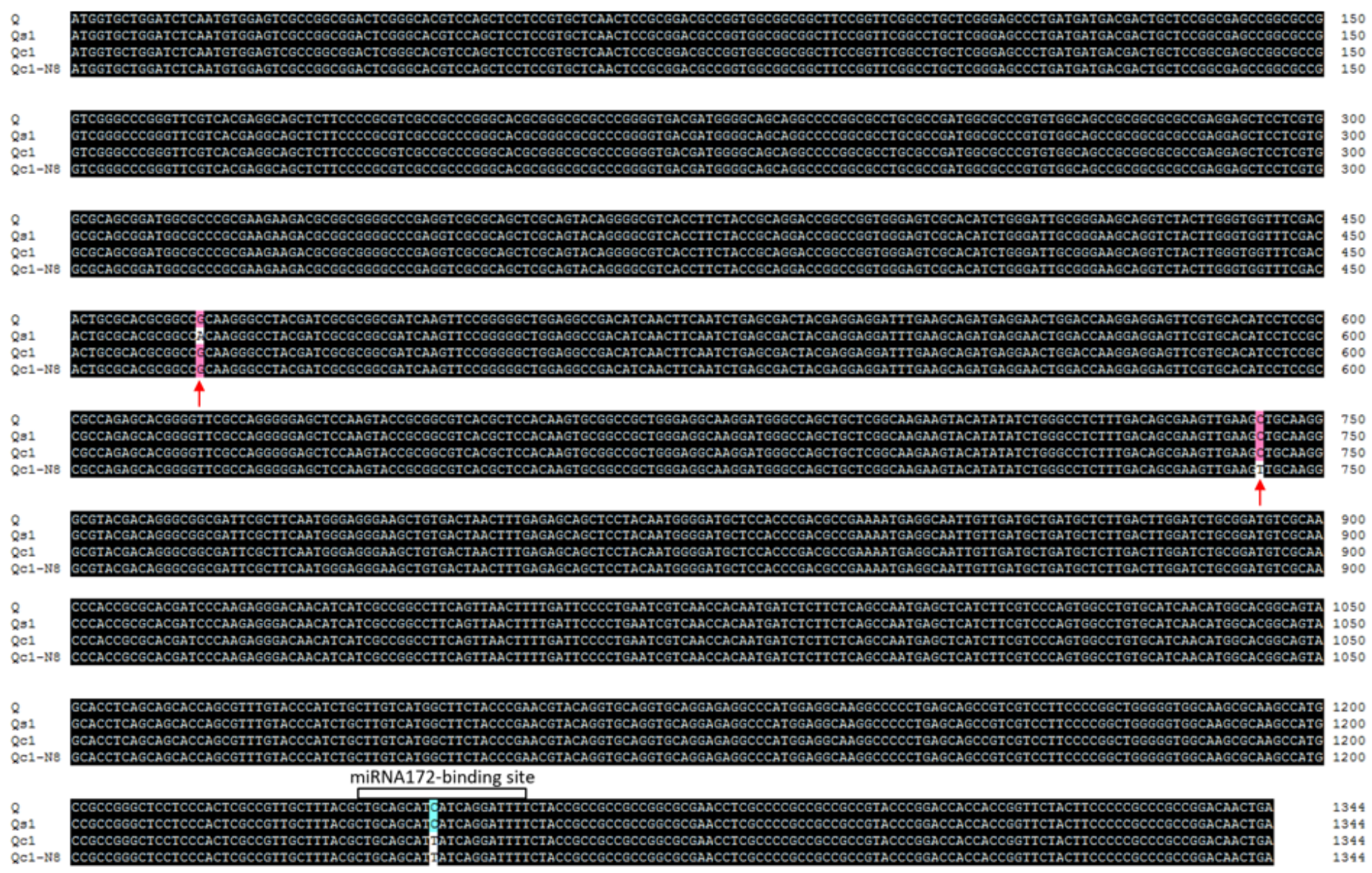

\section{Figure 3}

Alignment of the Q (GenBank No. KX580301.2), Qs1 (OK041024), Qc1 (KX580302.2), and Qc1-N8 (OK041023) open reading frames. The arrows indicate the two specific missense mutations in the Qs1 and Qc1-N8 alleles. The microRNA172-binding site is boxed 
Q AQRMAPAKKTRRGPRSRSSYRGVTFYRRTGRWESHIWDCGKQVYLGGEDTAHARZ FAYDRAAIRFRGLEADINFNLSDYEEDLRQMRNWTKEEFVHILR Q31 AQRMAFAKKTRRGPRSRSQYRGVTFYRRTGRWESHIWDCGKQVYLGGFDTAHA2 TEAYDRAAIKFRGLEADINFNLSDYEEDLKQMRNWTKEEFVHILR AQRMA PAKKTRRGPRSRSSQYRGVTFYRRTGRWESHIWDCGKQVYLGGEDTAHAD 7 FAYDRAAIRERGLEADINFNL SDYEEDLRCMRNWTKEEFVHILR QC1-N8 AQRMAPARRTRRGPRSRSSCYRGVTFYRRTGRWESHIWDCGRQVYLGGFDTAHAR

Nuclear Localizing Signal

AP2 domain R1

\begin{tabular}{|c|c|}
\hline Q & $\begin{array}{l}\text { RQSTGFARGSSRYRGVTLHRCGRWEARMGQLLLGKKYIYLGLFDSEV } \\
\text { ROSTGFARGSSRYRGVTLHRCGRWEARMGCLLGKRYIYLGLFDSV }\end{array}$ \\
\hline Qs1 & QSTGFARGSSRYRGVTLHRCGRWEARMGQLLLKKYIYLGLFDSE \\
\hline Qc1 & RQSTGFARGSSRYRGVTLHKCGRWEARMGQLLGKKYIYLGLFD \\
\hline$-\mathrm{N} 8$ & IGFARGSSKYRGVTLHRCGRWEARMGQLLGKRYIYLGLF \\
\hline & AP2 domain R2 \\
\hline Q & PTAHDPRRDNI IAGLQLL T FDSPESST TMISSQEMSSSSSQWFVH \\
\hline Qs1 & PTAHDPRRDNI IAGLQLTFDSPESST TMISSQPMSSSSSQWPVH \\
\hline Qc1 & PTAHDFKRDNI IAGLQLTFDSPESSTTMISSQPMSSSSSQWWPHQ \\
\hline -N8 & PTAHDPRRDNI IAGLQLTFDSPESSTTMISSQQEMSSSSSQ్WPV \\
\hline & AASSGF Box \\
\hline Q & AARSSGFSTAAAGANLAPPPPYPDHHRFYFPRF \\
\hline 31 & FPGSSHSPLLYAARSSGFSTAAAGANLAPFPFYPDHHRFYF PRF \\
\hline & PPGSSHSPLLYAAAISGFSTAAAGANLAPPPFYPDHHRFYFPRP \\
\hline & EPGSSHSPLLYAARISGFSTAAAGANLAPPPPYPDHHRFYFPRF \\
\hline
\end{tabular}
FAYDRAA IRERGLEADINFNLSDYEEDLRQMRNWTKEEFVHILR

\section{Figure 4}

Alignment of the deduced amino acid sequences encoded by the Q, Qs1, Qc1, and Qc1-N8 alleles. Seven previously described conserved domains (motif 1, motif 2, nuclear localization signal, AP2 domain R1, AP2 domain R2, motif 3, and AASSGF box) are presented (Gil-Humanes et al. 2009)
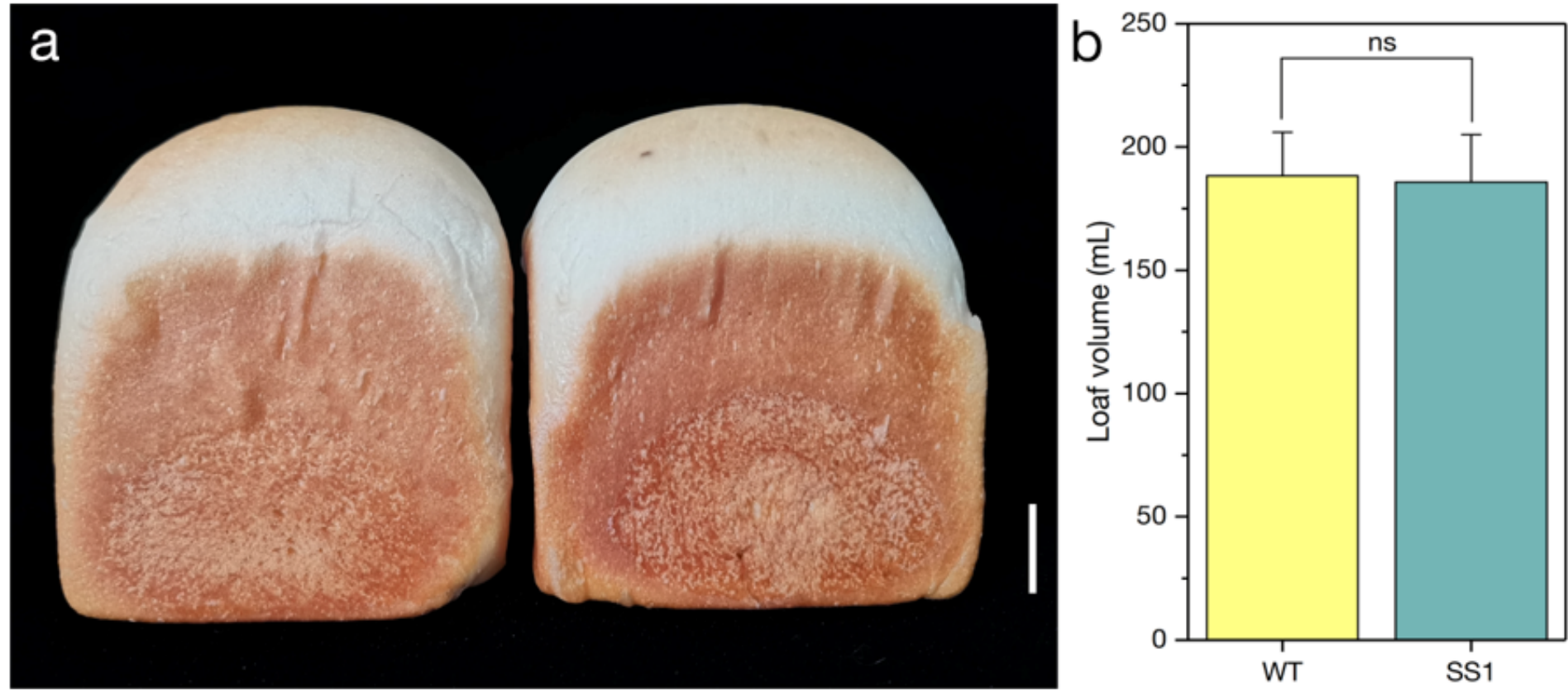

\section{Figure 5}

Qs1 has no effect on the bread loaf volume. (A) Comparison of the intact SS1 (left) and wild-type (WT) (right) loaves. Scale bar, $2 \mathrm{~cm}$. (B) Comparison of the SS1 and WT loaf volumes. ns, not significant 

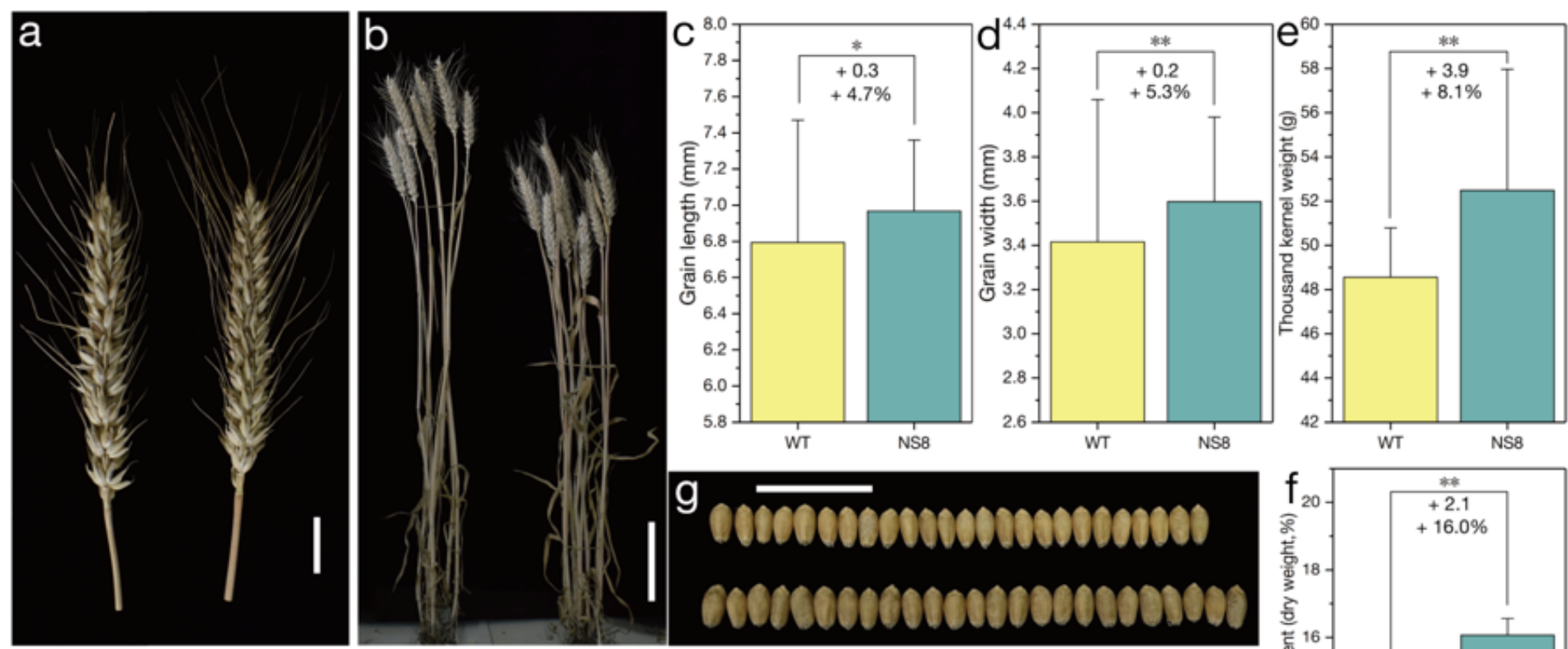

\section{h}
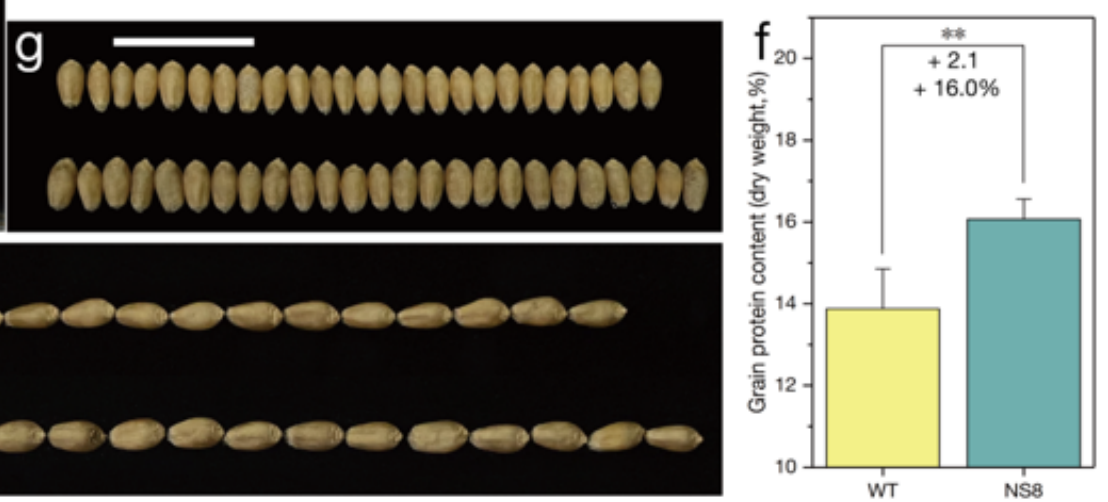

Figure 6

Phenotype of the mutant NS8. (a) Spikes of the wild-type (WT) (left) and NS8 (right) plants. Scale bar, 2 $\mathrm{cm}$. (b) WT (left) and NS8 (right) plants. Scale bar, $10 \mathrm{~cm}$. Comparisons of the grain length (c), grain width (d), thousand kernel weight (e), and grain protein contents (f) of the WT and NS8 samples. **, $P<$ $0.01 ;{ }^{*}, P<0.05$. Data are presented as the mean \pm standard deviation. ' + ' and ' - ' indicate more and less than the WT control, respectively. ' $+0.3^{\prime}$ in panel (c) indicates the NS8 grain was $0.3 \mathrm{~mm}$ longer than the WT grain (on average). ' $+4.7 \%$ ' in panel (c) indicates that Qc1-N8 increased the grain length by $4.7 \%$ (on average). (g) Kernel width of the WT (upper) and NS8 (lower) samples. Scale bar, $2 \mathrm{~cm}$. (h) Kernel length of the WT (upper) and NS8 (lower) samples. Scale bar, $2 \mathrm{~cm}$ 

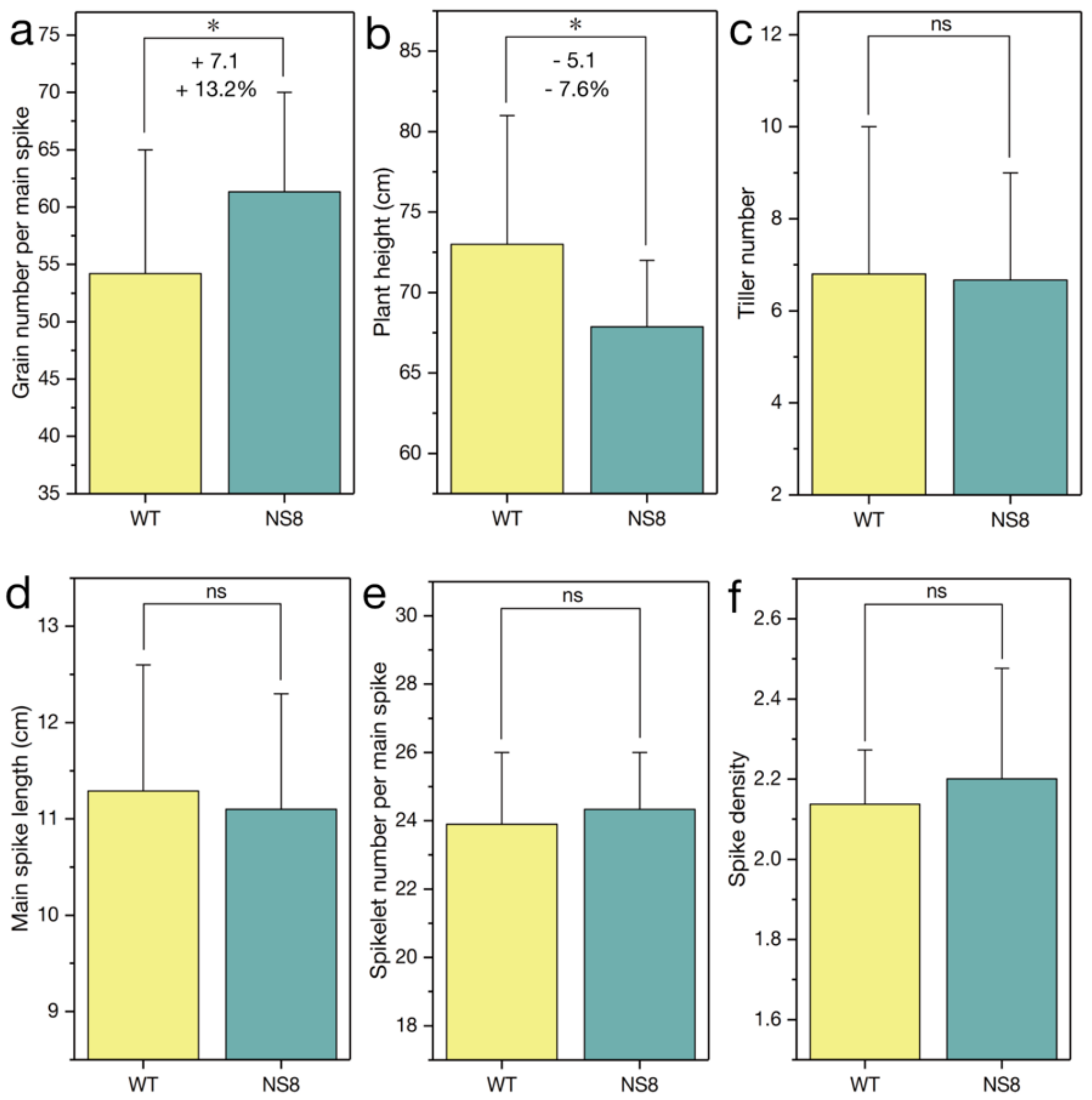

Figure 7

Effect of Qc1-N8 on agronomic traits. The data in the bar graphs are presented as the mean \pm standard deviation. *, $\mathrm{P}<0.05$; ns, not significant. ' + ' and ' - ' indicate more and less than the wild-type (WT) control, respectively. ' +7.1 ' in panel (a) indicates NS8 plants had 7.1 more grains per main spike than the WT plants (on average). '+ 13.2\%' in panel (a) indicates that Qc1-N8 increased the grain number per main spike by $13.2 \%$ (on average) 